Huber, B. E., Escudero, R., Busse, H. J., Seibold, E., Scholz, H. C., Anda, P., Kämpfer, P. \& Splettstoesser, W. D. (2010). Description of Francisella hispaniensis sp. nov., isolated from human blood, reclassification of Francisella novicida (Larson et al. 1955) Olsufiev et al. 1959 as Francisella tularensis subsp. novicida comb. nov., and emended description of the genus Francisella. Int J Syst Evol Microbiol 60, 18871896.

Koeppel, A., Perry, E. B., Sikorski, J., Krizanc, D., Warner, A., Ward, D. M., Rooney, A. P., Brambilla, E., Connor, N. \& other authors (2008). Identifying the fundamental units of bacterial diversity: a paradigm shift to incorporate ecology into bacterial systematics. Proc Natl Acad Sci U S A 105, 2504-2509.

Lapage, S. P., Sneath, P. H. A., Lessel, E. F., Skerman, V. B. D., Seeliger, H. P. R. \& Clark, W. A. (editors) (1992). International Code of Nomenclature of Bacteria (1990 Revision). Bacteriological Code. Washington, DC: American Society for Microbiology.

Larson, C. L., Wicht, W. \& Jellison, W. L. (1955). A new organism resembling $P$. tularensis isolated from water. Public Health Rep 70, 253-258.

Larsson, P., Elfsmark, D., Svensson, K., Wikström, P., Forsman, M., Brettin, T., Keim, P. \& Johansson, A. (2009). Molecular evolutionary consequences of niche restriction in Francisella tularensis, a facultative intracellular pathogen. PLoS Pathog 5, e1000472.

Olsufiev, N. G., Emelyanova, O. S. \& Dunayeva, T. N. (1959). Comparative study of strains of $B$. tularense in the old and new world and their taxonomy. J Hyg Epidemiol Microbiol Immunol 3, 138-149.

Skerman, V. B. D., McGowan, V. \& Sneath, P. H. A. (editors) (1980). Approved lists of bacterial names. Int J Syst Bacteriol 30, 225-420.

Tindall, B. J., Kämpfer, P., Euzéby, J. P. \& Oren, A. (2006). Valid publication of names of prokaryotes according to the rules of nomenclature: past history and current practice. Int J Syst Evol Microbiol 56, 2715-2720.

\title{
Objections to the transfer of Francisella novicida to the subspecies rank of Francisella tularensis - response to Johansson et al.
}

The description of novel species requires the careful selection and use of a wide variety of methodologies. As pointed out by Tindall et al. (2010), experience gained over the past six decades has continued to demonstrate the value of comparing different datasets and also of basing the description and delineation of taxa on as wide a dataset as possible. A combination of data acquired from DNA-based methods (DNA-DNA hybridization, gene sequences, genomic fingerprints) and phenotyping (chemotaxonomic, physiological and morphological traits) provides a sound basis for the taxonomy of the prokaryotes (Tindall et al., 2010). The decision as to whether two bacteria are members of a single species is still based on the results from DNA-DNA hybridizations (Wayne et al., 1987; Stackebrandt et al., 2002). In general, two bacterial strains are assigned to the same species if their DNAs reassociate at levels greater than $70 \%$ and $5 \%$ or less $\Delta T_{\mathrm{m}}$ (Wayne et al., 1987), but the latter criterion is only rarely applied. In addition, Wayne et al. (1987) pointed out 'Subspecies designations can be used for genetically close organisms that diverge in phenotype'.

Our proposal to transfer Francisella novicida as a novel subspecies to $F$. tularensis subsp. novicida is in agreement with the above-mentioned recommendations. As demonstrated by the results from DNA-DNA reassociation experiments, $F$. novicida is genetically close to F. tularensis (Hollis et al., 1989) and the phenotypic differences observed (Huber et al., 2010) are in agreement with the subspecies concept. Another important point supporting this taxonomic rearrangement is the acceptance of the new combination within the scientific community. The use of this not yet validly published new combination may be related to the fact that in Bergey's Manual of Systematic Bacteriology (often erroneously considered as the 'bible' of bacterial systematics by those interested in bacterial taxonomy), the transfer of $F$. novicida to Francisella tularensis subsp. novicida was recommended in the chapter dealing with the genus Francisella (Sjöstedt, 2005). Although this proposal was never formally recognized, numerous microbiologists are already using the name. An online search survey in 'Pubmed' (http://www.ncbi.nlm. nih.gov/sites/entrez?db=PubMed) indicates that in recent years there is no significant difference in the frequencies of the use of the names $F$. novicida and $F$. tularensis subsp. novicida.

From our point of view, it is not consistent to have a species $F$. tularensis with three subspecies supported by DNA-DNA relatedness data but distinguishable by phenotypic traits and a separate species $F$. novicida that also shares high DNA-DNA relatedness values $(>85 \%)$ but which is phenotypically distinguishable. Based on the results from the literature and the results from our investigations, but also for sake of consistency, it is obvious that our proposal to assign $F$. novicida to $F$. tularensis as a novel subspecies is well supported.

Below are some additional replies to certain arguments proposed by Johansson et al. (2010) to support their stance against the reclassification of $F$. novicida.

It is argued, that:

'From a practical standpoint, separate species names are useful in a microbiological laboratory or a clinical setting and also as a basis for regulations governing the handling of medically important organisms. [...] Importantly, it is fairly easy to distinguish $F$. novicida and F. tularensis on the basis of their different growth and metabolic requirements on artificial media'.

In contrast to tularaemia caused by $F$. tularensis subsp. tularensis or F. tularensis subsp. holarctica, human or animal infections with strains of $F$. tularensis subsp. novicida are extremely rare and there are very few publications reporting the isolation of this facultative pathogen. Most of these reports have shown that it was very difficult to distinguish those isolates from strains of $F$. tularensis, not only for routine clinical laborat- 
ories, but also for a reference laboratory (Birdsell et al., 2009). We have the impression that the majority of routine laboratories will not be able to distinguish between the two subspecies on the basis of phenotypic characteristics or metabolic requirements.

It is also difficult to understand why only separate species are useful in a microbiological laboratory or a clinical setting but not separate subspecies.

The same is true for the basis of regulations governing the handling of medically important organisms. In fact, there is a clear example showing that subspecies differentiation can be applied for different classification of medically important bacteria. According to EU guideline 2000/54/EC, which had to be translated into national law in 27 European countries, F. tularensis subsp. tularensis [Francisella tularensis (Type A)] is classified as a BSL 3 pathogen, while $F$. tularensis subsp. holarctica [Francisella tularensis (Type B)] is classified as a BSL 2 pathogen (European Communities, 2000; EU directive 2000/54/EC).

It is argued, that:

'Indeed, in Table 2 of Huber et al. (2010) data are provided that contradict their own proposal by presenting 11 metabolic reactions that are distinct between F. novicida and F. tularensis (Huber et al., 2010)'.

It is common knowledge that a bacterial species is composed of individuals that are not necessarily identical in their phenotypic traits. For instance, in the entry for Pseudomonas fluorescens in Bergey's Manual of Systematic Bacteriology (Palleroni, 2005), among 139 traits listed, fewer than $50 \%$ (62 traits) are identical among the different biovars of this species and 18 traits are listed in which biovar I strains are variable. Hence, we do not think that 11 traits distinguishing F. tularensis subsp. novicida among 98 traits tested contradict our proposal. In this context, it has also to be mentioned here that the type strain of Francisella tularensis subsp. holarctica differs from the other two subspecies in seven traits and in an additional four traits from one or the other subspecies (Huber et al., 2009).

It is argued that:

'In 1989, Hollis et al. (1989) showed that $F$. novicida and F. tularensis could be considered one species as judged from DNA-DNA hybridization experiments (Hollis et al., 1989). Their publication was not valid according to the requirements outlined in the Bacteriological Code (Lapage et al., 1992; Tindall et al., 2006). As a result, the proposed elimination of the species $F$. novicida and the demotion of it to a biogroup of F. tularensis was not included among prokaryotic names with standing in nomenclature'.

In the paper of Hollis et al. (1989), the authors presented data on which they proposed the transfer of Yersinia philomiragia to the genus Francisella as Francisella philomiragia comb. nov. Furthermore, based on results from DNA-DNA hybridizations $(>85 \%$ reassociation) they also proposed to transfer Francisella novicida to the species Francisella tularensis as the third biogroup Francisella tularensis biogroup novicida in addition to the biogroups tularensis and palaeartica. It is not clear why Hollis et al. (1989) did not apply the taxonomy proposed by Olsufjev \& Meshcheryakova (1983), who had subdivided $F$. tularensis into three subspecies, Francisella tularensis subsp. tularensis, Francisella tularensis subsp. holarctica and Francisella tularensis subsp. mediasiatica, or why they did not refer to the paper of Olsufjev \& Meshcheryakova (1983). In Validation List No. 32 (Hollis et al., 1990), the name Francisella philomiragia comb. nov. was validly published whereas the name $F$. tularensis biogroup novicida was not. This was because the Bacteriological Code does not cover infraspecific names (e.g. biogroups, biovars, pathovars etc.) other than subspecies names.

Hence, there is no scientific argument to state that the paper of Hollis et al. (1989) was not valid according to the requirements of the Bacteriological Code. Only the proposed name $F$. tularensis biogroup novicida could not be validly published according to the requirements of the Bacteriological Code. In fact the term 'valid' can only be applied to the valid publication of the name. This does not mean that the scientific conclusions of the paper of Hollis et al. (1989) are incorrect.

It is argued that:
'Notably, earlier publications con- sidered F. novicida and F. tularensis to be separate species based on differences in phenotype including chemotaxonomic markers, distinct ecological roles, different clinical and epidemiological characteris- tics, and differing abilities and modes of invasion and mechan- isms of tissue damage in mammals (Larson et al., 1955; Olsufiev et al., 1959; Skerman et al., 1980)'.

Microbiologists, including bacterial taxonomists, have always made use of the tools that are available to them at the time. Unfortunately, the paper of Olsufiev et al. (1959) was not accessible to us, but neither Larson et al. (1955) nor Skerman et al. (1980) mention any chemotaxonomic markers that they had examined. To the best of our knowledge, studies in bacterial taxonomy in the 1950s were restricted to ecological, physiological, morphological and serological examinations. Analyses of lowmolecular mass cell components such as fatty acids, polar lipids, quinones (chemotaxonomic markers) or DNAbased studies were not yet established, and hence it also appears likely that Olsufiev et al. (1959) did not examine chemotaxonomic markers. In the following decades, with the introduction of novel tools, new knowledge has been gained which has led to numerous reclassifications of established taxa. For instance, species assigned to the genus Pseudomonas in Bergey's Manual of Systematic Bacteriology (Palleroni, 1984) have since been shown to be distributed over the three classes Alphaproteobacteria, Betaproteobacteria and Gammaproteobacteria. As a result, species phylogenetically only distantly related to the genus Pseudomonas have been reclassified as species of other genera. A similar fate has befallen numerous other taxa. Hence, there is 
no reason why taxonomic conclusions concerning the genus Francisella proposed decades ago should remain untouchable when new findings suggesting reclassification are reported.

We agree with the authors of the letter that genomic data can provide an enormous amount of information. We think that bacterial taxonomy may undergo significant changes on the basis of the understanding of genomic and proteomic information. However, for the time being, we are far from able to interpret this information well enough to draw decisive conclusions. There are numerous open questions, e.g. 'Which genes belong to the conserved genome core considered useful to define a taxon and which belong to accessory dispensible genetic elements?' The impact of processes such as lateral gene transfer, gene duplication, recombination and rearrangements of genes in the genome is not clear and it may be very different in different lineages! For instance, the sizes of Escherichia coli genomes range from 4.6 to $5.7 \mathrm{Mb}$. This observation indicates that strains of a single species may lose or acquire $20-25 \%$ of their genome from other sources without affecting their taxonomic status. So, for the time being, it is more appropriate to rely on the generally applied approaches for delineating taxa including species and subspecies (for a review see Tindall et al., 2010). Reclassification of $F$. novicida as $F$. tularensis subsp. novicida is in agreement with these recommendations and also avoids confusion among those interested in bacterial taxonomy. Adhering to the species $F$. novicida might raise the question of why the other subspecies of $F$. tularensis have not been elevated to species level, though at least some arguments for the species $F$. novicida could also apply to the three recognized subspecies of $F$. tularensis.

\section{Hans-Jürgen Busse, ${ }^{1}$ Birgit Huber, ${ }^{1}$ Pedro Anda, ${ }^{2}$ Raquel Escudero, ${ }^{2}$}

Holger C. Scholz, ${ }^{3}$ Erik Seibold, ${ }^{3}$ Wolf D. Splettstoesser ${ }^{3}$ and Peter Kämpfer ${ }^{4}$

${ }^{1}$ Institut für Bakteriologie, Mykologie und Hygiene, Veterinärmedizinische Universität, A-1210 Wien, Austria

${ }^{2}$ Laboratorio de Espiroquetas y Patógenos Especiales, Centro Nacional de Microbiología Instituto de Salud Carlos III, Madrid, Spain

${ }^{3}$ Bundeswehr Institute of Microbiology, German Reference Laboratory for Tularemia, Neuherbergstr. 11, D-80937 Munich, Germany

${ }^{4}$ Institut für Angewandte Mikrobiologie, Justus-Liebig-Universität Giessen, D-35392 Giessen, Germany

Correspondence: Hans-Jürgen Busse (hans-juergen.busse@vetmeduni.ac.at)

Birdsell, D. N., Stewart, T., Vogler, A. J., Lawaczeck, E., Diggs, A., Sylvester, T. L., Buchhagen, J. L., Auerbach, R. K., Keim, P. \& Wagner, D. M. (2009). Francisella tularensis subsp. novicida isolated from a human in Arizona. BMC Res Notes 2, 223.

European Communities (2000). Directive 2000/ 54/EC of The European Parliament and of The Council. Off J Eur Communities L262, 2145.

Hollis, D. G., Weaver, R. E., Steigerwalt, A. G., Wenger, J. D., Moss, C. W. \& Brenner, D. J. (1989). Francisella philomiragia comb. nov. (formerly Yersinia philomiragia) and Francisella tularensis biogroup novicida (formerly Francisella novicida) associated with human disease. J Clin Microbiol 27, 1601-1608.

Hollis, D. G., Weaver, R. E., Steigerwalt, A. G., Wenger, J. D., Moss, C. W. \& Brenner, D. J. (1990). Francisella philomiragia comb. nov. In Validation of the Publication of New Names and New Combinations Previously Effectively Published Outside the IJSB, List no. 32. Int J Syst Bacteriol 40, 105-106.

Huber, B. E., Escudero, R., Busse, H.-J., Seibold, E., Scholz, H. C., Anda, P., Kämpfer, P. \& Splettstoesser, W. D. (2010). Description of Francisella hispaniensis sp. nov., isolated from human blood, reclassification of Francisella novicida (Larson et al. 1955) Olsufiev et al. 1959 as Francisella tularensis subsp. novicida comb. nov., and emended description of the genus Francisella. Int J Syst Evol Microbiol 60, 18871896.

Johansson, A., Celli, J., Conlan, W., Elkins, K. L., Forsman, M., Keim, P. S., Larsson, P., Manoil,
C., Nano, F. E. \& other authors (2010).

Objections to the transfer of Francisella novicida to the subspecies rank of Francisella tularensis. Int J Syst Evol Microbiol 60, 1717-1718.

Larson, C. L., Wicht, W. \& Jellison, W. L. (1955). A new organism resembling $P$. tularensis isolated from water. Public Health Rep 70, 253-258.

Olsufiev, N. G., Emelyanova, O. S. \& Dunayeva, T. N. (1959). Comparative study of strains of $B$. tularense in the old and new world and their taxonomy. J Hyg Epidemiol Microbiol Immunol 3, 138-149.

Olsufjev, N. G. \& Meshcheryakova, I. S. (1983). Subspecific taxonomy of Francisella tularensis McCoy and Chapin 1912. Int J Syst Bacteriol 33, 872-874.

Palleroni, N. J. (1984). Genus 1. Pseudomonas Migula $1894237^{\mathrm{AL}}$. In Bergey's Manual of Systematic Bacteriology, vol. 1, pp. 141-199. Edited by N. R. Krieg \& J. G. Holt. Baltimore: Williams \& Wilkins.

Palleroni, N. J. (2005). Genus I. Pseudomonas Migula $1894237^{\mathrm{AL}}$. In Bergey's Manual of Systematic Bacteriology, 2nd edn, vol. 2, part B, pp. 323-379. Edited by D. J. Brenner, N. R. Krieg, J. T. Staley \& G. M. Garrity. New York: Springer.

Sjöstedt, A. B. (2005). Genus I. Francisella Dorofe' ev 1947, 176 ${ }^{\mathrm{AL}}$. In Bergey's Manual of Systematic Bacteriology, 2nd edn, vol. 2, part B, pp. 200-210. Edited by D. J. Brenner, N. R. Krieg, J. T. Staley \& G. M. Garrity. New York: Springer.

Skerman, V. B. D., McGowan, V. \& Sneath, P. H. A. (editors) (1980). Approved lists of bacterial names. Int J Syst Bacteriol 30, 225420.

Stackebrandt, E., Frederiksen, W., Garrity, G. M., Grimont, P. A. D., Kämpfer, P., Maiden, M. C. J., Nesme, X., Rossello-Mora, R., Swings, J. \& other authors (2002). Report of the ad hoc committee for the re-evaluation of the species definition in bacteriology. Int J Syst Evol Microbiol 52, 10431047.

Tindall, B. J., Rosselló-Móra, R., Busse, H.-J., Ludwig, W. \& Kämpfer, P. (2010). Notes on the characterization of prokaryote strains for taxonomic purposes. Int J Syst Evol Microbiol 60, 249-266.

Wayne, L. G., Brenner, D. J., Colwell, R. R., Grimont, P. A. D., Kandler, O., Krichevsky, M. I., Moore, L. H., Moore, W. E. C., Murray, R. G. E. \& other authors (1987). International Committee on Systematic Bacteriology. Report of the ad hoc committee on reconciliation of approaches to bacterial systematics. Int J Syst Bacteriol 37, 463464. 